\title{
On the Taxonomic Status of 'Quin's Oval' Organisms
}

\author{
BY A. J. WICKEN* AND B. H. HOWARD \\ Department of Biochemistry, Lincoln College, University of Canterbury, \\ Canterbury, New Zealand
}

(Accepted for publication 7 December 1966)

SUMMARY

Purified suspensions of the sheep rumen organism known colloquially as 'Quin's oval' were prepared from sheep rumen liquor. The chemical composition of cell walls prepared from the organisms of these suspensions was found to include protein, lipid and polysaccharide. A fraction from these walls, obtained after removal of much of the protein and polysaccharide, was shown to contain muramic acid, glucosamine and diaminopimelic acid. These findings are consistent with this organism being regarded as a Gramnegative bacterium.

\section{INTRODUCTION}

Quin (1943) appears to have been the first to describe an ovoid organism found in sheep rumen, which, because of its yeast-like appearance and its fermentative ability he called Schizosaccharomyces ovis. The same organism was observed by McGaughey \& Sellers (1948) who found that it became predominant in the rumen of a hay-fed sheep when the diet was supplemented with mangolds. Ingram \& McGaughey (1948) could not cultivate the organism in media used for the growth of yeasts and concluded that it was not a yeast. This conclusion was supported by van der Westhuizen, Oxford \& Quin (1950) and Oxford (1955). The latter author considered that the organism had not yet been validly named, and workers with rumen micro-organisms have since then contented themselves with reference to it as 'Quin's oval organism' (Q.O.).

We have prepared suspensions of Q.O. from rumen liquor, free from protozoa and virtually free from bacteria, by differential centrifugation. The organisms were obtained in a metabolically active form, and the results of fermentation studies will be reported elsewhere. We present now, as a contribution to the taxonomy of Q.O., some observations on the chemical composition of its cell wall.

\section{METHODS}

Isolation of organism. The sheep used in these experiments was fitted with a rumen cannula. It was fed on lucerne hay ad lib. and also consumed about $200 \mathrm{~g}$. molasses/day dissolved in the drinking water. Rumen liquor, drawn through the cannula $2 \mathrm{hr}$ after the morning feed, was strained through muslin and incubated at $38^{\circ}$ for $1 \mathrm{hr}$. The scum was carefully removed by suction and glucose was then added to the remaining brown cloudy fluid at a rate of $0.75 \mathrm{~g}$. $/ 100 \mathrm{ml}$ liquor. After a further $1 \mathrm{hr}$ period of incubation, the fluid was centrifuged for $5 \mathrm{~min}$. in the cold, $\mathrm{RCF}_{\max \text {. }}=70 \mathrm{~g}$ (Inter-

* Present address: Department Microbiology, School of Biological Sciences, University of New South Wales, Kensington, N.S.W., Australia. 
national Refrigerated Centrifuge, model PR2, head no. 276). The supernatant fluid was removed by suction and the greenish residue resuspended in half the original volume of buffer solution (Abou Akkada \& Howard, 1960). The suspension was centrifuged as before and the residue discarded. The original supernatant fluid plus washings was centrifuged for $30 \mathrm{~min} ., \mathrm{RCF}_{\max .}=1000 \mathrm{~g}$ (head no. 269) and the cloudy supernatant fluid, containing many bacteria but very few Q.O., was discarded. The creamy-white precipitate was resuspended in buffer solution and centrifuged again. This washing process was repeated until the supernatant fluid was almost clear and microscopic examination of Gram-stained preparations of the precipitate showed it to be virtually free from micro-organisms other than Q.O. The large size of Q.O. in comparison with other bacteria enabled this distinction to be made readily. For the cleanest preparations ( $<1$ bacterium/500 Q.O.) it was found necessary to centrifuge, during the washing stage, at a $\mathrm{RCF}_{\max .}=800 \mathrm{~g}$ with accompanying loss of Q.O. The oval organisms, which averaged $6 \times 4 \mu$ in size, showed no marked internal features under phase-contrast microscopy, were markedly Gram-negative and the use of nuclear stains did not show a discrete nucleus. In fresh rumen samples, examined microscopically on a warm-stage, the ovals were actively motile. Motility was rapidly lost during the purification procedure but could be partially restored by warming the ovals to $37^{\circ}$ in buffer. Refractile granules as reported by McGaughey \& Sellers (1948) were not observed. Flagellated crescent forms (McGaughey \& Sellers, 1948) have been observed by us in samples of rumen liquor but were completely absent from these preparations of Q.O. Preparations of Q.O. were finally washed with $0.9 \%(\mathrm{w} / \mathrm{v})$ saline and stored in the frozen state as a $20 \%(\mathrm{w} / \mathrm{v})$ suspension in saline.

Preparation of cell walls of Q.O. Cell walls were prepared and purified essentially as described by Forrester \& Wicken (1966).

Electron microscopy. Suspensions of whole organisms or of cell walls were prepared in distilled water and air dried on 200-mesh carbon-backed collodion grids. Specimens were shadowed at a $30^{\circ}$ angle with $\mathrm{Au}+\mathrm{Pd}$ and examined in a Hitachi HU-11 B electron microscope by Mr M. K. Reynolds of the Plant Diseases Division, DSIR, Lincoln, Canterbury, New Zealand.

Chemical methods. Acid hydrolysis of cell walls and chromatographic identification of hydrolysis products was done by methods described previously (Forrester \& Wicken, 1966) with the addition of thin-layer chromatography on cellulose + silica gel for amino acid identification (Turner \& Redgwell, 1966). Quantitative analyses of phosphorus, lipid and hexosamines were made as previously described (Forrester \& Wicken, 1966), neutral sugars by the quantitative paper chromatographic method of Wilson (1959) and nitrogen by combustion analysis (Coleman Nitrogen Analyser).

\section{RESULTS}

Final preparations of cell walls of Q.O. were free of cytoplasmic constituents as judged by their appearance under the electron microscope and, although thin, retained the rigid shape of the original organism (Pl. 1, fig. 1). Electron micrographs (PI. 1, fig. 2) of whole organisms showed clearly the presence of peritrichous flagella. Marked fragmentation of the latter occurred when suspensions of Q.O. were frozen and then thawed; this fragmentation did not occur during storage over several days at $5^{\circ}$.

Amino acids in cell walls. Seventeen amino acids were identified by thin layer 
chromatography. Alanine, threonine, glycine, serine, glutamic acid, aspartic acid, methionine, valine, leucine and isoleucine appeared as major components; arginine, histidine, lysine, cysteine, proline, tyrosine and diaminopimelic acid were shown as minor components. Diaminopimelic acid was further characterized by paper chromatography in several solvent systems (Forrester \& Wicken, 1966) and by high voltage paper electrophoresis. On paper, but not on thin-layer plates, the characteristic yellow ninhydrin colour of diaminopimelic acid 'spots' was observed.

Table 1. Composition of the cell walls of Q.O.

$\begin{array}{lclc} & \begin{array}{c}\% \text { by weight of } \\ \text { dry cell wall }\end{array} & \begin{array}{c}\% \text { by weight of } \\ \text { dry cell wall }\end{array} \\ \text { Nitrogen } & 9 \cdot 82 & \text { Glucose } & 0.9 \\ \text { *Hexosamines } & 7.77 & \text { Galactose } & 1.3 \\ \text { Lipid } & 9.92 & \text { Rhamnose } & 9 \cdot 0 \\ \text { Total phosphorus } & 0.54 & \text { Ribose } & 0.9 \\ \text { Lipid phosphorus } & 0 \cdot 19 & & \\ & \text { * Determined as glucosamine equivalents. }\end{array}$

Table 2. Chromatographic mobility of muramic acid prepared from Q.O. compared with authentic muramic acid

\section{Chromatographic system}

1. Phenol + water $(3+1$ by vol) TLC $\uparrow$

2. Butan -2- ol + formic acid + water $(7+1+2$ by vol. $)$ TLC $\dagger$

3. Propan-2-ol+water ( $4+1$ by vol.), paper

4. Butan-1-ol+acetic acid + water $(4+1+5$ by vol., upper layer), paper

5. Butan-1-ol + pyridine + water ( $6+4+3$ by vol.), paper

6. Ethylacetate + pyridine $+\mathrm{H}_{2} \mathrm{O}+$ acetic acid $(5+5+3+1$ by vol.), paper

$\begin{array}{cc}\begin{array}{c}\text { Muramic acid } \\ \text { from Q.0. }\end{array} & \begin{array}{c}\text { Muramic acid } \\ \text { (authentic)* }\end{array} \\ 2.95 & 2.95 \\ 2.05 & 2.00 \\ & R_{\text {glucosamine }} \\ 1.10 & 1.10 \\ 1.92 & 1.98 \\ 1.18 & 1.20 \\ 1.14 & 1.12\end{array}$

* Authentic muramic acid from Sigma Chemical Co., U.S.A.

+ TLC $=$ thin-layer chromatography on cellulose + silica gel (Turner \& Redgwell, 1966).

Neutral sugars in cell walls. Glucose, galactose, rhamnose and ribose were positively identified in acid hydrolysates by paper chromatography in several solvent systems. Traces of an unknown sugar with an $R_{F}$ value corresponding to arabinose, but which was not a pentose, were also found. The Dische reaction (Dische \& Shettles, 1948; Salton, 1964) for aldoheptoses carried out with whole cell walls and with material eluted from the hexose region of paper chromatograms of wall acid hydrolysates all proved negative.

Hexosamines in cell walls. Glucosamine was identified in acid hydrolysates of whole cell walls by its $R_{F}$ value on paperchromatograms, ninhydrin oxidation product and the spectrum of the chromogen formed in a modified Elson-Morgan reaction (Boas, 1953).

The results of quantitative analyses are recorded in Table 1.

Degradation products characteristic of teichoic acids were not found in acid hydrolysates of wall preparations. 
A fractionation scheme, involving tryptic digestion and extraction with sodium dodecylsulphate solutions, devised for the preparation of glycosaminopeptides from the cell walls of Gram-negative bacteria (Grula, Smith \& Grula, 1965), was applied to cell walls from Q.O. Much of the protein and polysaccharide components of the wall were solubilized by this method, while the residual particulate matter retained the rigid shape of the original cell-wall fragments. Chromatograms of acid hydrolysates of the latter still showed traces of both neutral sugars and the full range of amino acids but the hexosamine fraction was greatly enriched, as were the amino acids, alanine, glycine, glutamic acid and $\alpha, \epsilon$-diaminopimelic acid. Chromatography on Whatman $3 \mathrm{MM}$ paper in butan-1-ol + acetic acid + water $(4+1+5$, by vol. upper layer) gave glucosamine and a component having the mobility of muramic acid in this solvent $\left(R_{\text {gltcosammine }}=1.92\right)$. This material had an $R_{F}$ value identical with that of authentic muramic acid in five other paper and thin-layer chromatographic systems (Table 2). The spectral curves of the chromogens produced in a modified Elson-Morgan reaction (Boas, 1953; Strominger, Park \& Thompson, 1959) with muramic acid from Q.O. and authentic muramic acid were identical. Peak absorption occurred at $505 \mathrm{~m} \mu$ compared with $525 \mathrm{~m} \mu$ and $526 \mathrm{~m} \mu$ for glucosamine and galactosamine respectively, and an increase of absorption at $505 \mathrm{~m} \mu$ was noted after $24 \mathrm{hr}$.

\section{DISCUSSION}

Q.O. appears 'featureless' under phase-contrast microscopy and in stained preparations, a property in keeping with it being a lower rather than a higher protist. That it is Gram-negative might also be considered at variance with the original view that this organism was a yeast, yeasts being generally Gram-positive. Later views (van der Westhuizen, Oxford \& Quin, 1950) that Q.O. is not a yeast appear to have been based on a failure of laboratory culture in media which usually grow yeasts. As far as we are aware Q.O. has not been grown in any medium outside the rumen (see McGaughey \& Sellers, 1948) and thus such conclusions might be considered premature.

In recent years extensive chemical and biochemical studies of microbial cell walls have been made. It is now evident (Salton, 1964) that the cell walls of algae, yeasts and fungi are predominantly polysaccharide in nature, although protein and lipid are significant constituents in some species. Bacteria, on the other hand, are further distinguished in that the bacterial walls contain glycosaminopeptide heteropolymers, which lend structural rigidity to the wall, and, in many cases, also teichoic acids.

Glycosaminopeptides are characteristically composed of the two amino sugars, glucosamine and muramic acid and a limited number (4-5) of amino acids. $\alpha-\epsilon$-Diaminopimelic acid is a widely occurring constituent of bacterial glycosaminopeptide and the cell walls of most Gram-negative bacteria thus far examined have been shown to contain this amino acid (Salton, 1964). Muramic acid has been found in all bacterial cell walls thus far examined as well as in the blue green algae and appears to be confined to the lower protists (Salton, 1964). More recently the finding of muramic acid in the cell walls of rickettsias (Allison \& Perkins, 1960) and spirochaetes (Ginger, 1963) has been used as the main evidence for justifying the inclusion of these groups of micro-organisms among the bacteria.

The isolated cell walls of Q.O. have been shown to contain protein (from the wide range of amino acids found in acid hydrolysates), polysaccharide and lipid, which are 
Journal of General Microbiology, Vol. 47, No. 2

Plate 1
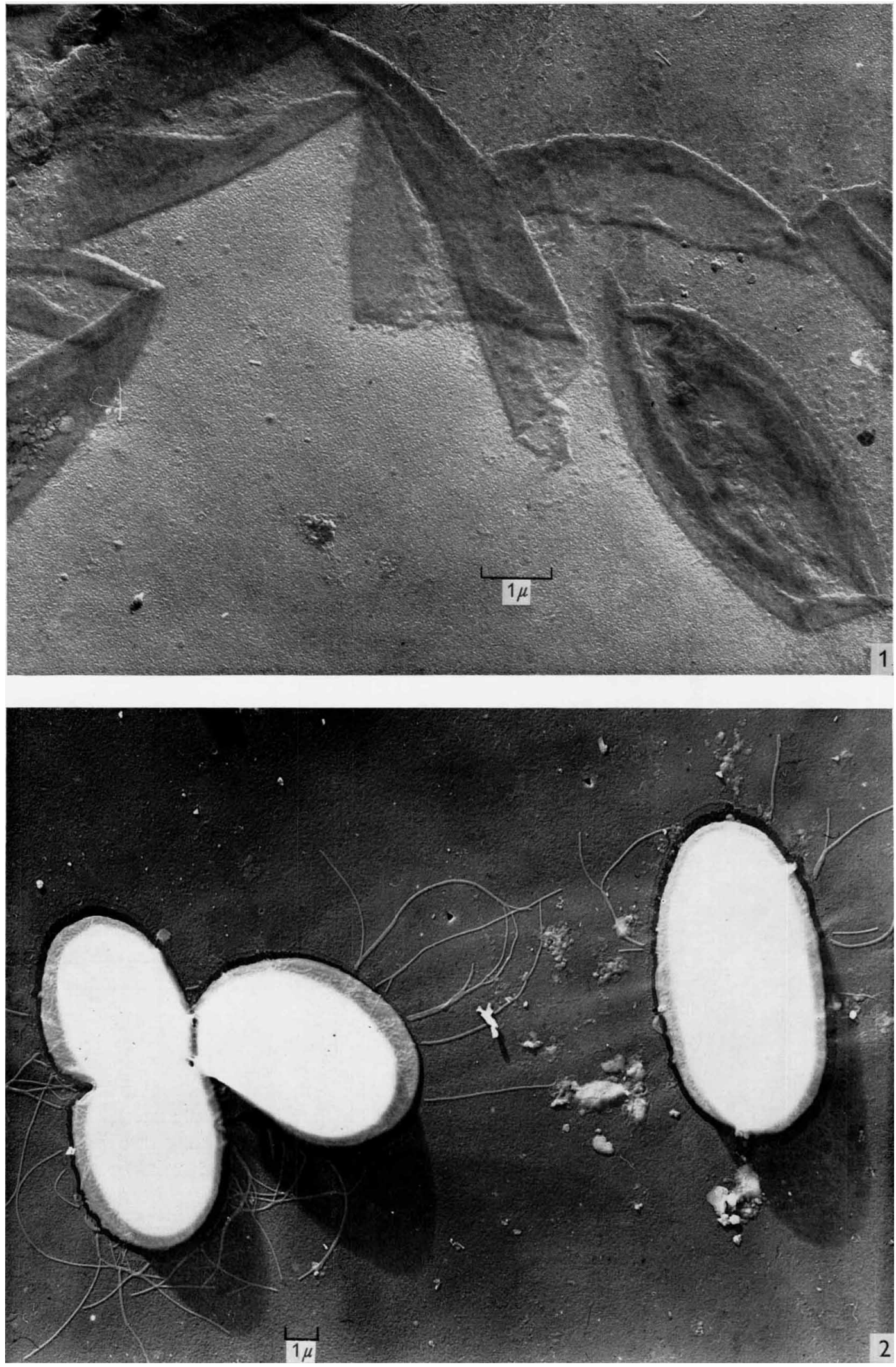
components typical of Gram-negative bacteria (Salton, 1964). In addition, a partially purified fraction of the wall, obtained after removal of much of the protein and polysaccharide and which retained the rigidity of the original cell wall, contained glucosamine and muramic acid. The amino acid composition of this impure glycosaminopeptide could not be determined unequivocally owing to incomplete removal of wall protein but the enrichment, in this fraction, of alanine, glycine, glutamic acid and, particularly, diaminopimelic acid is consistent with the amino acid composition of glycosaminopeptides from other Gram-negative bacteria. Teichoic acid appears to be absent from these cell walls as is the case with most Gram-negative bacteria but it is interesting to note that only a third of the low phosphorus content of the wall is associated with wall lipid. The organic nature of the remaining phosphorus is not known.

In view of the chemical composition of the cell wall of Q.O. we conclude that it is a member of the bacteria (Schizomycetes).

We thank Mr G. G. Thomson for cannulating the sheep used in these experiments and acknowledge research grants from the N.Z. University Grants Research Committee and the Nuffield Foundation (N.Z.)

\section{REFERENCES}

Abou Akkada, A. R. \& Howard, B. H. (1960). The biochemistry of rumen protozoa. 3. The carbohydrate metabolism of Entodinium. Biochem. J. 76, 445.

Allison, A. C. \& Perkins, H. R. (1960). Presence of cell walls like those of bacteria in Rickettsiae. Nature, Lond. 188, 796.

BoAs, N. F. (1953). Method for the determination of hexosamines in tissues. J. biol. Chem. $204,553$.

Dische, Z. \& SheTtles, L. B. (1948). A specific colour reaction of methylpentoses and a spectrophotometric micromethod for their determination. J. biol. Chem. 175, 595.

ForRester, I. T. \& WiCKEN, A. J. (1966). The chemical composition of the cell walls of some thermophilic bacteria. J. gen. Microbiol. 42, 147.

GINGER, C. D. (1963). Isolation and characterization of muramic acid from two spirochaetes: Borrelia duttoni and Leptospira biflexa. Nature, Lond. 199, 159.

Grula, E. A., Smith, G. L. \& Grula, M. M. (1965). Cell division in a species of Erwinia. VIII. Amino acid composition of the mucopeptide in dividing and non-dividing cells. Canad. J. Microbiol. 11,605 .

IngRam, M. \& McGaughey, C. A. (1948). Microflora of the rumen of the sheep. Nature, Lond. $162,533$.

McGaughey, C. A. \& Sellers, K. C. (1948). Microflora of the rumen. Nature, Lond. 161, 1014.

OxFORD, A. E. (1955). Some observations upon the status of the generic name Selenomonas Prowazek. Int. Bull. bact. Nomencl. Taxon. 5, 131.

QuIN, J. I. (1943). Studies on the alimentary tract of Merino sheep in South Africa. VII. Fermentation in the fore stomachs of sheep. Onderstepoort J. vet. Sci. 18, 91.

Salton, M. R. J. (1964). The Bacterial Cell Wall. London: Elsevier Publishing Co.

Strominger, J. L., PARK, J. T. \& Thompson, R. E. (1959). Composition of the cell wall of Staphylococcus aureus: its relation to the mechanism of action of penicillin. J. biol. Chem. 234, 3263.

Turner, N. A. \& ReDGwell, R. J. (1966). A mixed layer for the separation of amino acids by thinlayer chromatography. J. Chromat, $21,129$.

van Der Westhuizen, G. C. A., OXFord, A. E. \& Quin, J. I. (1950). Studies on the alimentary tract of Merino sheep in South Africa. XVI. On the identity of Schizosaccharomyces ovis. Part I. Some yeast-like organisms isolated from the rumen contents of sheep fed on a lucerne diet. Onderstepoort. J. vet. Sci. 24, 119.

Wrison, C. M. (1959). Quantitative determination of sugars on paper chromatograms. Analyt. Chem. 31, 1199.

\section{EXPLANATION OF PLATE}

Fig. 1. Electron micrograph of a cell-wall preparation from 'Quin's oval' .

Fig. 2. Electron micrograph of whole organisms of 'Quin's oval' showing the type of peritrichous flagellation. 